\title{
Synthesis of rare-earth metal and rare-earth metal-fluoride nanoparticles in ionic liquids and propylene carbonate
}

\author{
Marvin Siebels ${ }^{1}$, Lukas Mai ${ }^{2}$, Laura Schmolke ${ }^{1}$, Kai Schütte ${ }^{1}$, Juri Barthel ${ }^{3}$, Junpei Yue ${ }^{4}$, \\ Jörg Thomas ${ }^{5}$, Bernd M. Smarsly ${ }^{4}$, Anjana Devi ${ }^{2}$, Roland A. Fischer ${ }^{6}$ \\ and Christoph Janiak ${ }^{* 1}$
}

\author{
Full Research Paper \\ Address: \\ ${ }^{1}$ Institut für Anorganische Chemie und Strukturchemie, \\ Heinrich-Heine-Universität Düsseldorf, 40204 Düsseldorf, Germany. \\ Fax: +49-211-81-12287; Tel: +49-211-81-12286, ${ }^{2}$ Inorganic Materials \\ Chemistry, Ruhr-Universität Bochum, 44801 Bochum, Germany, \\ ${ }^{3}$ Gemeinschaftslabor für Elektronenmikroskopie RWTH-Aachen, \\ Ernst Ruska-Centrum für Mikroskopie und Spektroskopie mit \\ Elektronen, 52425 Jülich, Germany, ${ }^{4}$ Physikalisch-Chemisches \\ Institut, Justus-Liebig-Universität Gießen, 35392 Gießen, Germany, \\ ${ }^{5}$ Department Structure and Nano-/Micromechanics of Materials, \\ Max-Planck-Institut für Eisenforschung $\mathrm{GmbH}, 40237$ Düsseldorf, \\ Germany and ${ }^{6}$ Department of Chemistry, Technische Universität \\ München, 85748 Garching, Germany \\ Email: \\ Christoph Janiak ${ }^{*}$ - janiak@uni-duesseldorf.de \\ * Corresponding author \\ Keywords: \\ ionic liquids; metal amidinates; rare-earth metal-fluoride \\ nanoparticles; rare-earth metal nanoparticles; soft wet-chemical \\ synthesis \\ Beilstein J. Nanotechnol. 2018, 9, 1881-1894. \\ doi:10.3762/bjnano.9.180 \\ Received: 27 March 2018 \\ Accepted: 30 May 2018 \\ Published: 28 June 2018 \\ Associate Editor: J. J. Schneider \\ (c) 2018 Siebels et al.; licensee Beilstein-Institut. \\ License and terms: see end of document.
}

Open Access

\begin{abstract}
Decomposition of rare-earth tris $\left(N, N^{\prime}\right.$-diisopropyl-2-methylamidinato)metal(III) complexes $\left[\operatorname{RE}\left\{\operatorname{MeC}\left(\mathrm{N}(\mathrm{iPr})_{2}\right)\right\}_{3}\right]\left(\mathrm{RE}(\mathrm{amd})_{3}\right.$; $\mathrm{RE}=\operatorname{Pr}(\mathrm{III}), \mathrm{Gd}(\mathrm{III}), \mathrm{Er}(\mathrm{III}))$ and tris(2,2,6,6-tetramethyl-3,5-heptanedionato)europium(III) $\left(\mathrm{Eu}(\mathrm{dpm})_{3}\right)$ induced by microwave heating in the ionic liquids (ILs) 1-butyl-3-methylimidazolium tetrafluoroborate ([BMIm][BF 4$]$ ), 1-butyl-3-methylimidazolium bis(trifluoromethylsulfonyl)imide ([BMIm] $\left.\left[\mathrm{NTf}_{2}\right]\right)$ and in propylene carbonate (PC) yield oxide-free rare-earth metal nanoparticles (RE-NPs) in [BMIm] $\left[\mathrm{NTf}_{2}\right]$ and $\mathrm{PC}$ for $\mathrm{RE}=\mathrm{Pr}, \mathrm{Gd}$ and Er or rare-earth metal-fluoride nanoparticles $\left(\mathrm{REF}_{3}-\mathrm{NPs}\right)$ in the fluoridedonating IL $\left.\left[\mathrm{BMIm}_{[}\right] \mathrm{BF}_{4}\right]$ for $\mathrm{RE}=\mathrm{Pr}, \mathrm{Eu}, \mathrm{Gd}$ and Er. The crystalline phases and the absence of significant oxide impurities in RE-NPs and REF $_{3}$-NPs were verified by powder X-ray diffraction (PXRD), selected area electron diffraction (SAED) and highresolution X-ray photoelectron spectroscopy (XPS). The size distributions of the nanoparticles were determined by transmission electron microscopy (TEM) and high-angle annular dark-field scanning transmission electron microscopy (HAADF-STEM) to an average diameter of $(11 \pm 6)$ to $(38 \pm 17) \mathrm{nm}$ for the $\mathrm{REF}_{3}-\mathrm{NPs}_{\mathrm{s}}$ from [BMIm] $\left.\mathrm{BF}_{4}\right]$. The RE-NPs from [BMIm] $\left.\mathrm{NTf}_{2}\right]$ or PC showed diameters of $(1.5 \pm 0.5)$ to $(5 \pm 1) \mathrm{nm}$. The characterization was completed by energy-dispersive X-ray spectroscopy (EDX).
\end{abstract}




\section{Introduction}

Rare-earth (RE) elements gain increasing importance in materials science and modern chemistry [1-3]. Special attention has been paid to nanoscaled rare-earth metal particles [4-6]. In addition to the oxido and nitrido compounds, the rare-earth fluorides have interesting photo physical and electrochemical properties. An important representative of this category are $\mathrm{AREF}_{4}$ compounds ( $\mathrm{A}=$ alkali metal), with unique optical, magnetic and piezoelectric properties [7]. They are applied in solid-state lasers, three-dimensional flat-panel displays, and low-intensity IR imaging [8]. Syntheses of these $\mathrm{AREF}_{4}$-type compounds are based on the liquid precipitation reaction between soluble rareearth metal salts and alkaline fluorides. A co-thermolysis of $\mathrm{Na}\left(\mathrm{CF}_{3} \mathrm{COO}\right)$ and $\mathrm{RE}\left(\mathrm{CF}_{3} \mathrm{COO}\right)$ in oleic acid/oleylamine for the synthesis of $\mathrm{NaREF}_{4}(\mathrm{RE}=\mathrm{Er}(\mathrm{III}), \mathrm{Tm}(\mathrm{III}))$ has also been described [8]. One problem of these syntheses is that the obtained rare-earth fluoride particles were not phase-pure [8].

An alternative method for synthesizing rare-earth metal-fluoride nanoparticles is the use of rare-earth metal amidinates as precursors [9-12]. Metal amidinates are coordination compounds $[13,14]$ and used, for example, as catalysts in the polymerization of olefins $[15,16]$ and as precursors in chemical vapor (CVD) processes of rare-earth materials such as oxides and nitrides [17-19]. It is especially advantageous that the decomposition products from the amidinate ligand are gaseous so that product contamination is minimized [20]. Herein, we report the use of rare-earth amidinates $\mathrm{RE}(\mathrm{amd})_{3}$ with $\mathrm{RE}=\operatorname{Pr}(\mathrm{III})$, Gd(III), Er(III) and of tris(2,2,6,6-tetramethyl-3,5-heptanedionato)europium(III) $\left(\mathrm{Eu}(\mathrm{dpm})_{3}\right)$ as precursors for rare-earth metal-fluoride nanoparticles $\left(\mathrm{REF}_{3}\right.$-NPs) by microwaveassisted thermal syntheses in the ionic liquid (IL) 1-butyl-3methylimidazolium tetrafluoroborate $\left([\mathrm{BMIm}]\left[\mathrm{BF}_{4}\right]\right)$ with the reactive $\mathrm{BF}_{4}$ anion as a fluoride source (Scheme 1). For the synthesis of $\mathrm{EuF}_{3}-\mathrm{NPs}$, the precursor $\mathrm{Eu}(\mathrm{dpm})_{3}$ was used, since a europium amidinate, $\mathrm{Eu}(\mathrm{amd})_{3}$ is not yet known in the literature and therefore not available. In general metal-fluoride nanoparticles, are important in materials science and modern chemistry $[21,22]$.

However, in the absence of fluoride donors we obtained oxidefree rare-earth metal nanoparticles (RE-NPs) of Pr, Gd and Er (Scheme 1). By using either the chemically more inert IL 1-butyl-3-methylimidazolium bis(trifluoromethylsulfonyl)imide $\left([\mathrm{BMIm}]\left[\mathrm{NTf}_{2}\right]\right)$ or propylene carbonate $(\mathrm{PC})$ as reaction media RE-NPs were produced. This is an unusual and quite interesting result that we wish to highlight at this point. There exist only few reports on the wet-chemical synthesis of nanoparticles of rare-earth metals or rare-earth metal containing alloys or intermetallic phases. Solution synthesis of any oxide-free RE-NP was first reported by Wagner and co-workers using

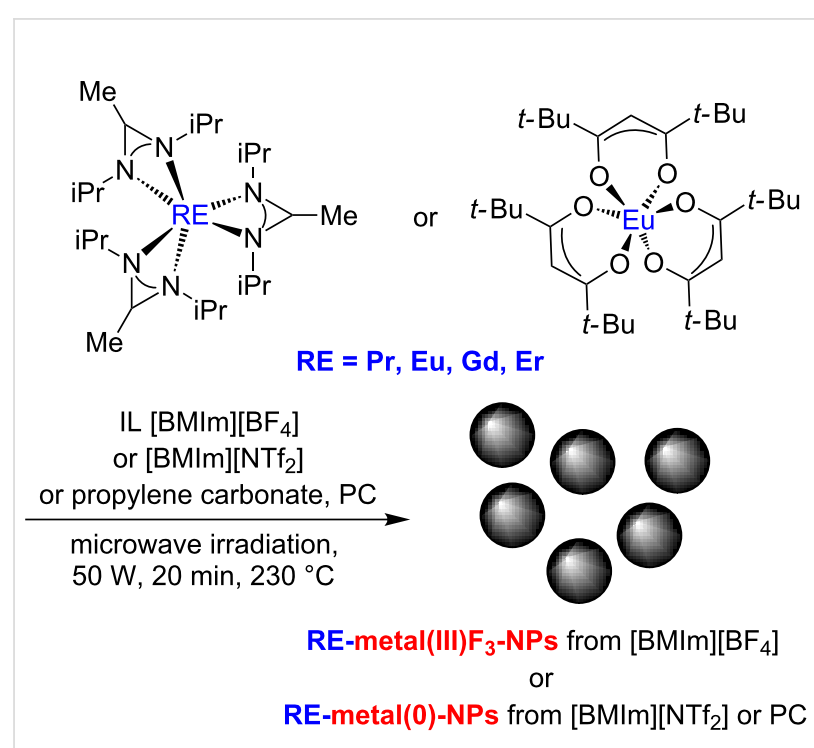

Scheme 1: Synthesis of $\mathrm{REF}_{3}$-NPs or RE-NPs from the rare-earth metal amidinates $\mathrm{RE}(\mathrm{amd})_{3}$ and $\mathrm{Eu}(\mathrm{dpm})_{3}$ by microwave-assisted thermal decomposition in the ionic liquids $[\mathrm{BMIm}]\left[_{[} \mathrm{BF}_{4}\right],[\mathrm{BMIm}]\left[\mathrm{NTf}_{2}\right]$ and $\mathrm{PC}$.

alkalide reduction of $\mathrm{GdCl}_{3}$ in THF solution [6]. Scalable airand water-stable core-shell Gd@Au-NPs were obtained by using the same strategy [23]. Rare-earth metal containing intermetallic nano-phases have been suggested as novel materials for various catalytic applications [24]. For example, $\mathrm{Pt}_{3} \mathrm{Y}$ and $\mathrm{Pt}_{5} \mathrm{Gd}$ were predicted to be more active as $\mathrm{Pt}$ in the oxygen reduction reaction (ORR) [25]. Nevertheless, the high reduction potentials of rare-earth metal ions (typically below $-2.0 \mathrm{~V}$ vs NHE) cause much difficulties regarding the chemical reduction of any chosen precursor and the prevention of post-synthesis oxidation or contamination of the RE-NPs. Recently, Alivisatos and co-authors reported on the synthesis of $\mathrm{Pt}_{3} \mathrm{Y}$ and other so-called early-late intermetallic nanoparticles by a solvent-free route employing a melt of the reducing agent $(\mathrm{Na} / \mathrm{K}) \mathrm{BEt}_{3} \mathrm{H}$ [26]. We like to put our results into this context. Herein we demonstrate that $\mathrm{RE}(\mathrm{amd})_{3}$ releases the RE component by selective thermolysis even in the absence of additional reducing agents. Microwave heating and employing suitable ILs and PC as inert reaction media proved to be crucial.

Ionic liquids are used as stabilizing reagents and as solvents in syntheses of nanoparticles [27-31]. In contrast to conventional stabilizers, such as surfactants or polymers, the ILs stabilize the particles via electrostatic and steric interactions without altering the surface properties [32-37]. In addition, they have a high thermal stability, negligible vapor pressure and are not flammable [38]. PC is an aprotic, highly dipolar solvent with low viscosity $[39,40]$, low flammability and low toxicity [41]. 


\section{Results and Discussion \\ Decomposition of $\operatorname{RE}(\mathrm{amd})_{3}$ and $\mathrm{Eu}(\mathrm{dpm})_{3}$}

Thermogravimetric analysis (TGA) revealed decomposition of the rare-earth metal(III) tris $\left(N, N^{\prime}\right.$-diisopropyl-2-methylamidinate) $\left(\mathrm{RE}(\mathrm{amd})_{3} ; \mathrm{RE}=\operatorname{Pr}(\mathrm{III}), \mathrm{Gd}(\mathrm{III}), \operatorname{Er}(\mathrm{III})\right.$ and tris(2,2,6,6tetramethyl-3,5-heptanedionato)europium(III) $\left(\mathrm{Eu}(\mathrm{dpm})_{3}\right)$ at temperatures between 160 and $230{ }^{\circ} \mathrm{C}$ (Table S1 and Figure S2, Supporting Information File 1). To keep the formation of by-products as low as possible and to achieve complete decomposition of the precursors, a temperature of $230^{\circ} \mathrm{C}$ was selected on the basis of these TGA measurements for all microwaveassisted thermal NP syntheses. As reaction media we used the fluorous IL 1-butyl-3-methylimidazolium tetrafluoroborate ([BMIm] $\left.\left[\mathrm{BF}_{4}\right]\right)$ and 1-butyl-3-methylimidazolium bis(trifluoromethylsulfonyl)imide ([BMIm] $\left.\left[\mathrm{NTf}_{2}\right]\right)$ and the organic solvent propylene carbonate (PC) (Figure S3, Supporting Information File 1).

The rare-earth metal amidinates and $\mathrm{Eu}(\mathrm{dpm})_{3}$ were suspended under an argon atmosphere in dried IL or in PC. The compounds were decomposed by microwave irradiation for $20 \mathrm{~min}$ at a power of $50 \mathrm{~W}$ at a temperature of $230{ }^{\circ} \mathrm{C}$ (Scheme 1). The size distributions of the obtained nanoparticles were determined by transmission electron microscopy (TEM) and highangle annular dark-field scanning transmission electron microscopy (HAADF-STEM). The crystalline phases and the absence of impurities (oxides) in RE-NPs and $\mathrm{REF}_{3}-\mathrm{NPs}$ were identified by powder X-ray diffraction (PXRD) and selected area electron diffraction (SAED). The results are summarized in Table 1.

\section{$\mathrm{REF}_{3}-\mathrm{NPs}$ from $\mathrm{RE}(\mathrm{amd})_{3}$ and $\mathrm{Eu}(\mathrm{dpm})_{3}$ in [BMIm] $\left[\mathrm{BF}_{4}\right]$}

The microwave-induced decomposition of the rare-earth metal amidinates $\mathrm{RE}(\mathrm{amd})_{3}$ with $\mathrm{RE}=\operatorname{Pr}(\mathrm{III}), \mathrm{Gd}(\mathrm{III}), \operatorname{Er}(\mathrm{III})$ and $\mathrm{Eu}(\mathrm{dpm})_{3}$ in the fluorine-containing IL $[\mathrm{BMIm}]\left[\mathrm{BF}_{4}\right]$ gave green $\left(\mathrm{PrF}_{3}\right)$, white $\left(\mathrm{EuF}_{3}, \mathrm{GdF}_{3}\right)$ and rose-coloured $\left(\mathrm{ErF}_{3}\right)$ $1.0 \mathrm{wt} \%$ dispersions of $\mathrm{REF}_{3}$-NPs in IL.

Schmitz et al. synthesized $\mathrm{REF}_{3}-\mathrm{NPs}$ with $\mathrm{RE}=\mathrm{Pr}$, Eu, supported on different types of thermally reduced graphite oxide (TRGO) in [BMIm] $\left[\mathrm{BF}_{4}\right]$ [12]. The formation of $\mathrm{REF}_{3}-\mathrm{NPs}_{\mathrm{s}}$ is due to the $\left[\mathrm{BF}_{4}\right]^{-}$anion in the IL $[\mathrm{BMIm}]\left[\mathrm{BF}_{4}\right]$. The $\left[\mathrm{BF}_{4}\right]^{-}$ anion hydrolyzes or decomposes to fluoride $\mathrm{F}^{-}$with small amounts of residual water in the IL (30 ppm) which is very difficult to remove from hydrophilic [BMIm] $\left[\mathrm{BF}_{4}\right][12,42]$. It is also known that the $\left[\mathrm{BF}_{4}\right]^{-}$anion decomposes to fluoride at high temperature [43]. According to ion chromatographic (IC) analysis, a fluoride source other than the $[\mathrm{BF}]^{-}$anion can be excluded since the IL contains only a very small amount of fluoride ions (below $1 \mathrm{ppm}$, see Experimental section for IC

\begin{tabular}{|c|c|c|}
\hline precursor & $\begin{array}{c}\text { phase, identity of } \\
\text { RE-/REF }-\mathrm{NPs}^{\mathrm{b}} \\
{[\mathrm{BMIm}]\left[\mathrm{BF}_{4}\right]}\end{array}$ & $\begin{array}{l}\text { TEM diameter } \\
{[\mathrm{nm}]^{\mathrm{C}}}\end{array}$ \\
\hline $\operatorname{Pr}(\mathrm{amd})_{3}$ & $\mathrm{PrF}_{3}$ & $11 \pm 6$ \\
\hline $\mathrm{Eu}(\mathrm{dpm})_{3}$ & $\mathrm{EuF}_{3}$ & $23 \pm 7$ \\
\hline $\mathrm{Gd}(\mathrm{amd})_{3}$ & $\mathrm{GdF}_{3}$ & $38 \pm 17$ \\
\hline $\mathrm{Er}(\mathrm{amd})_{3}$ & $\mathrm{ErF}_{3}$ & $14 \pm 5$ \\
\hline \multicolumn{3}{|c|}{ [BMIm][NTf $\left.{ }_{2}\right]$} \\
\hline $\operatorname{Pr}(\mathrm{amd})_{3}$ & $-^{d}$ & $-^{d}$ \\
\hline $\mathrm{Eu}(\mathrm{dpm})_{3}$ & $-^{d}$ & $-^{d}$ \\
\hline $\mathrm{Gd}(\mathrm{amd})_{3}$ & $\mathrm{Gd}^{\mathrm{e}}$ & $1.5 \pm 0.5$ \\
\hline $\operatorname{Er}(\mathrm{amd})_{3}$ & $\mathrm{Er}^{\mathrm{e}}$ & $3.0 \pm 0.5$ \\
\hline \multicolumn{3}{|c|}{$\mathrm{PC}$} \\
\hline $\operatorname{Pr}(\mathrm{amd})_{3}$ & $\mathrm{Pr}^{\mathrm{e}}$ & $2 \pm 1$ \\
\hline $\mathrm{Eu}(\mathrm{dpm})_{3}$ & $-{ }^{d}$ & $-^{d}$ \\
\hline $\mathrm{Gd}(\mathrm{amd})_{3}$ & $\mathrm{Gd}^{\mathrm{e}}$ & $1.5 \pm 0.5$ \\
\hline $\operatorname{Er}(\mathrm{amd})_{3}$ & $\mathrm{Er}^{\mathrm{e}}$ & $5 \pm 1$ \\
\hline \multicolumn{3}{|c|}{$\begin{array}{l}\mathrm{a}_{1.0} \mathrm{wt} \% \mathrm{RE} / \mathrm{REF}_{3}-\mathrm{NP} / \mathrm{IL} \text { or in PC dispersions obtained by micro- } \\
\text { wave irradiation with } 50 \mathrm{~W} \text { for } 20 \text { min at } 230^{\circ} \mathrm{C} \text {. }{ }^{\mathrm{b}} \text { The phases of the } \\
\text { nanoparticles were identified by PXRD and SAED. }{ }^{\mathrm{C}} \text { Average diameter } \\
\text { and standard deviation } \sigma \text {. See Experimental section for TEM measure } \\
\text { ment conditions. }{ }^{\mathrm{d}} \text { No separated nanoparticles. }{ }^{\mathrm{e}} \text { No reflections in the } \\
\text { PXRD. }\end{array}$} \\
\hline
\end{tabular}

analysis conditions) [44,45]. Alternatively, reactive metal atoms or metal clusters may also abstract fluoride from $\left[\mathrm{BF}_{4}\right]^{-}$anions. ILs are not only solvents but can also be reactants, e.g., [BMIm] $\left[\mathrm{PF}_{6}\right]$ in the synthesis of $\mathrm{A}_{2} \mathrm{SiF}_{6}$ nanoparticles $(\mathrm{A}=\mathrm{Li}$, $\mathrm{Na}, \mathrm{K}, \mathrm{Rb}, \mathrm{Cs}$ ) [46], in the synthesis of $\mathrm{MF}_{x}$ nanoparticles ( $\mathrm{M}=\mathrm{Mn}, \mathrm{Fe}, \mathrm{Co}, \mathrm{Pr}, \mathrm{Eu}$ ) from the decomposition of transitionmetal amidinates in $[\mathrm{BMIm}]\left[\mathrm{BF}_{4}\right][12,42]$ or in the synthesis of metal-fluoride nanoparticles from metal acetate (hydrate) in ethylene glycol and an excess of [BMIm] $\left[\mathrm{BF}_{4}\right][47]$.

The sizes and size distributions of the $\mathrm{REF}_{3}$ nanoparticles were determined by HAADF-STEM (Figure S4a, Supporting Information File 1) and TEM (Figure 1 and Figures S5a and S6a, Supporting Information File 1) to values of 5-33 nm for $\mathrm{PrF}_{3}$, 6-35 nm for $\mathrm{EuF}_{3}, 17-67 \mathrm{~nm}$ for $\mathrm{GdF}_{3}$ and 8-22 $\mathrm{nm}$ for $\mathrm{ErF}_{3}$. The average particle sizes are $11 \pm 6 \mathrm{~nm}$ for $\operatorname{PrF}_{3}, 23 \pm 7 \mathrm{~nm}$ for $\mathrm{EuF}_{3}, 38 \pm 17 \mathrm{~nm}$ for $\mathrm{GdF}_{3}$, and $14 \pm 5 \mathrm{~nm}$ for $\mathrm{ErF}_{3}$ (Table 1). STEM/TEM images show small, nearly spherical and partially agglomerated particles. Close-up TEM images show interference patterns for $\mathrm{EuF}_{3}$ and $\mathrm{ErF}_{3}$, which indicate crystallinity of the $\mathrm{REF}_{3}$-NPs (Figure 1 middle, and Figure S5a, Supporting Information File 1).

The crystallinity of the particles was confirmed and the crystal phases were determined as pure rare-earth fluorides $\mathrm{REF}_{3}$ 

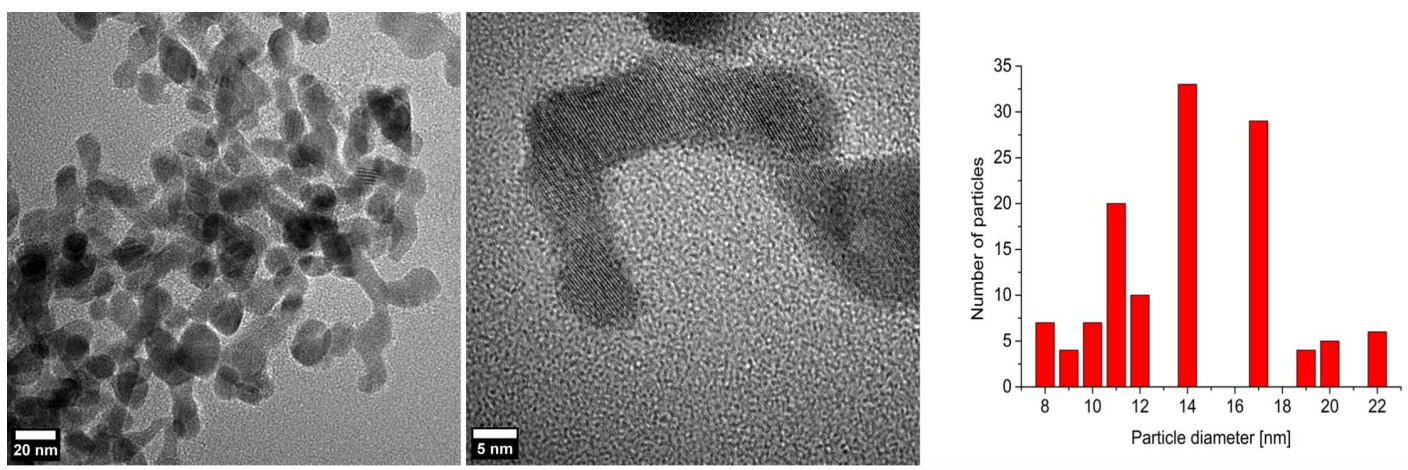

Figure 1: TEM images and particle size histogram (from 128 particles) of $1.0 \mathrm{wt} \% \mathrm{ErF}_{3}-\mathrm{NPs}_{\mathrm{s}}$ in $[\mathrm{BMIm}]\left[\mathrm{BF}_{4}\right]$ from $\mathrm{Er}(\mathrm{amd})_{3}$. Here and in the other TEM histogram evaluations the size measurements were done assuming approximately spherical particles. Differentiation of the overlapping particles was done with magnified images and with the help of the fine contrast.

$(\mathrm{RE}=\operatorname{Pr}(\mathrm{III}), \mathrm{Eu}(\mathrm{III}), \mathrm{Gd}(\mathrm{III}), \mathrm{Er}(\mathrm{III}))$ by powder X-ray diffractometry (PXRD) (Figure 2 and Figures S4b, S5b, S6b, Supporting Information File 1). In addition, the crystalline phases of $\mathrm{GdF}_{3}$ (Figure S6b, Supporting Information File 1) and $\mathrm{ErF}_{3}$ NPs (Figure 2) were assigned by selected area electron diffraction (SAED).

The characterization was completed by energy-dispersive X-ray spectroscopy (EDX, in combination with TEM) for the qualitative element composition. EDX spectroscopy (Figure 3 and Figures S5b, S6c, Supporting Information File 1) show the expected signals for $\mathrm{Eu}, \mathrm{Gd}$ or Er and fluoride besides the bands for carbon and copper of the carbon-coated copper grid. The oxygen peak can largely be attributed to air contamination when the sample was introduced into the TEM device. A quantification of fluoride against rare-earth metal was not done, because matching of the $F K \alpha_{1}$ binding energy against the $L \alpha_{1}$ or $L \beta_{1}$ binding energies for $\mathrm{Eu}, \mathrm{Gd}$ and $\mathrm{Er}$ is not very accurate.

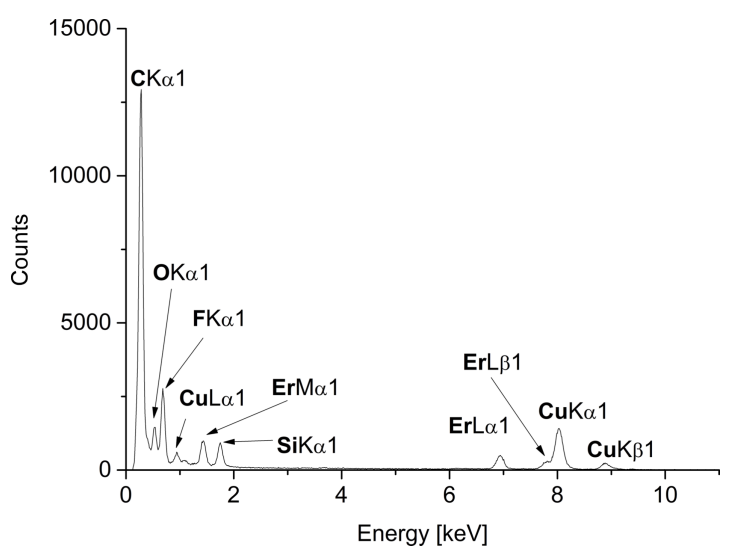

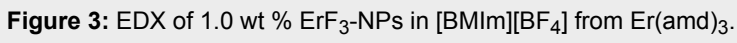
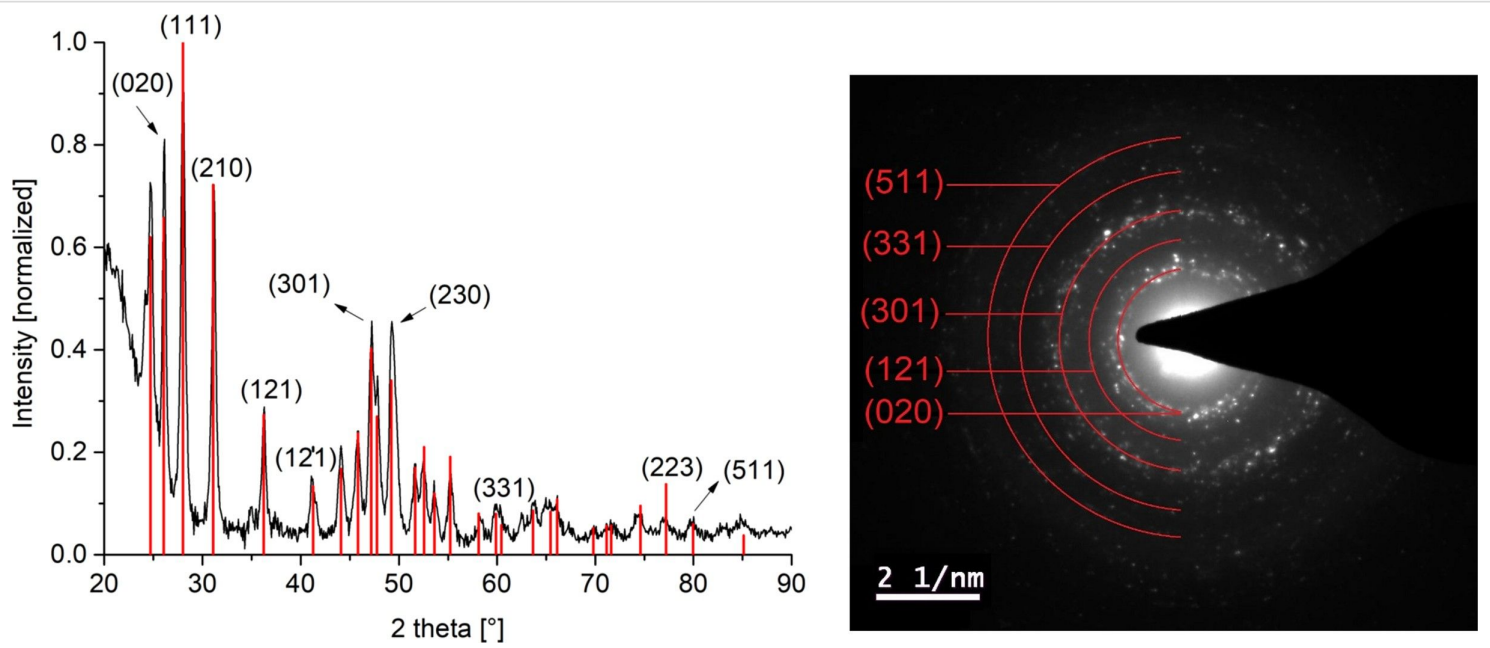

Figure 2: PXRD and SAED $\left(\mathrm{ErF}_{3}\right.$ reference peaks in red from $\mathrm{COD} 4030804$, orthorhombic structure with space group Pnma) of $1.0 \mathrm{wt} \% \mathrm{ErF}{ }_{3}-\mathrm{NPs}$ in $[\mathrm{BMIm}]\left[\mathrm{BF}_{4}\right]$ from $\mathrm{Er}(\mathrm{amd})_{3}$. 
The measured oxidation state $3+$ of the rare-earth metals in the fluorides was corroborated by high-resolution X-ray photoelectron spectroscopy (HR-XPS) (Figure 4 and Figures S4c, S5c, S6d, Supporting Information File 1) through comparison to the reported binding energies of metal(III) fluorides/oxides, metal( 0$)$ and organic fluorine/oxygen (Table 2) [48,49]. The measured metal and fluorine XPS values are in good agreement with the values of metal(III) fluorides that are given in litera- ture and thereby exclude the formation of metal(0) and the presence of organic fluoride (from residual IL). In addition, the formation of metal oxides can be excluded, since the measured binding energies of oxygen match very well with the literature values of organic oxygen $[48,49]$. For $\mathrm{EuF}_{3}$, no oxygen peak was seen in the XPS analysis. Therefore, SAED and PXRD data in combination with HR-XPS exclude any contamination of the $\mathrm{REF}_{3}$-NPs with metal(III) oxides.
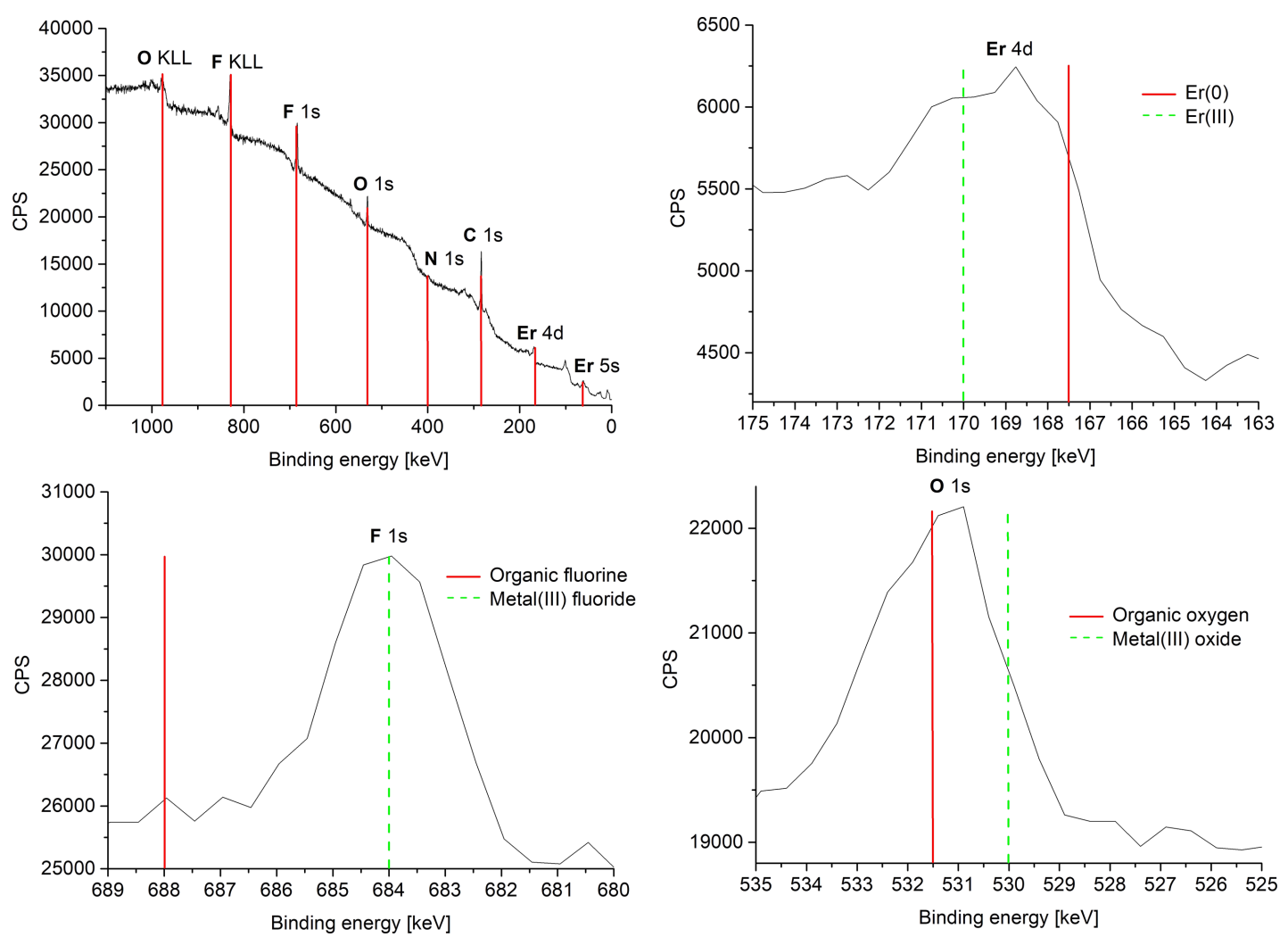

Figure 4: Overview and HR-XPS of $1.0 \mathrm{wt} \% \mathrm{ErF}_{3}-\mathrm{NPs}$ in $[\mathrm{BMIm}]\left[\mathrm{BF}_{4}\right]$ from $\mathrm{Er}(\mathrm{amd})_{3}$. The red and green bars are a guide to the eye on the bindingenergy axis.

Table 2: Comparison of XPS binding energies in $\mathrm{REF}_{3}-\mathrm{NP}$ samples in $[B M I m]\left[B F_{4}\right]$.

XPS signal measured $[\mathrm{eV}]$

metal(III) fluorides/oxides $[\mathrm{eV}]$
\[ [48,49] \]

$\mathrm{PrF}_{3}$

$\begin{array}{cc}\operatorname{Pr} 3 d_{5 / 2} & 934.5 \\ \text { F 1s } & 686 \\ \text { O 1s } & 533\end{array}$

$933-936^{a}$

$684-685.5^{\mathrm{a}}$

$529-530^{a}$

932

688-689

531.5-533 and organic

fluorine/oxygen [eV] $[48,49]$

\begin{tabular}{cccc}
\hline & & & \\
& & & \\
\hline Eu $3 d_{5 / 2}$ & 1135.5 & $1135^{a}$ & 1126 \\
F 1s & 685.5 & $684-685.5^{a}$ & $688-689$ \\
O 1s & no signal & $529-530^{a}$ & $531.5-533$
\end{tabular}


Table 2: Comparison of XPS binding energies in $\mathrm{REF}_{3}-\mathrm{NP}$ samples in $\left[\mathrm{BMIm}^{-}\left[\mathrm{BF}_{4}\right]\right.$. (continued)

$\mathrm{GdF}_{3}[50]$

\begin{tabular}{cccc}
\hline${\mathrm{Gd} 3 \mathrm{~d}_{3 / 2}}$ & 1220 & $1220^{\mathrm{a}}$ & 1218 \\
$\mathrm{Gd} \mathrm{3d_{5/2 }}$ & 1188 & $1188^{\mathrm{a}}$ & 1186 \\
$\mathrm{Gd} 4 \mathrm{~d}$ & 142.5 & $144^{\mathrm{a}}$ & 140 \\
$\mathrm{~F}$ 1s & 684 & $684-685.5^{\mathrm{a}}$ & $688-689$ \\
O 1s & 531.5 & $529-530^{\mathrm{a}}$ & $531.5-533$ \\
\hline & & & 167.5 \\
\hline Er 4d & $\mathrm{ErF}_{3}$ & $170^{\mathrm{a}}$ & $688-689$ \\
$\mathrm{~F}$ 1s & 169 & $684-685.5^{\mathrm{a}}$ & $531.5-533$ \\
\hline
\end{tabular}

aEntry corresponds to the measured experimental value.

Metal fluorides are used, for example, as cathode materials in lithium-ion batteries [6]. The lithium-ion battery is one of the most important rechargeable energy storage devices in modern electrical appliances such as mobile phones and laptops, but also in electric and hybrid vehicles [51]. The increasing performance of modern lithium-ion batteries is of great interest in cur- rent research [52-54]. Grey et al. showed that the use of $\mathrm{FeF}_{2}$ nanoparticles as electrode material leads to a significant increase in the performance of the batteries compared to the macroscopic $\mathrm{LiFeF}_{3}$ [55]. Therefore, we investigated the electrochemical properties of $\mathrm{ErF}_{3}-\mathrm{NPs}$ by galvanostatic charge/discharge profiles (Figure 5).
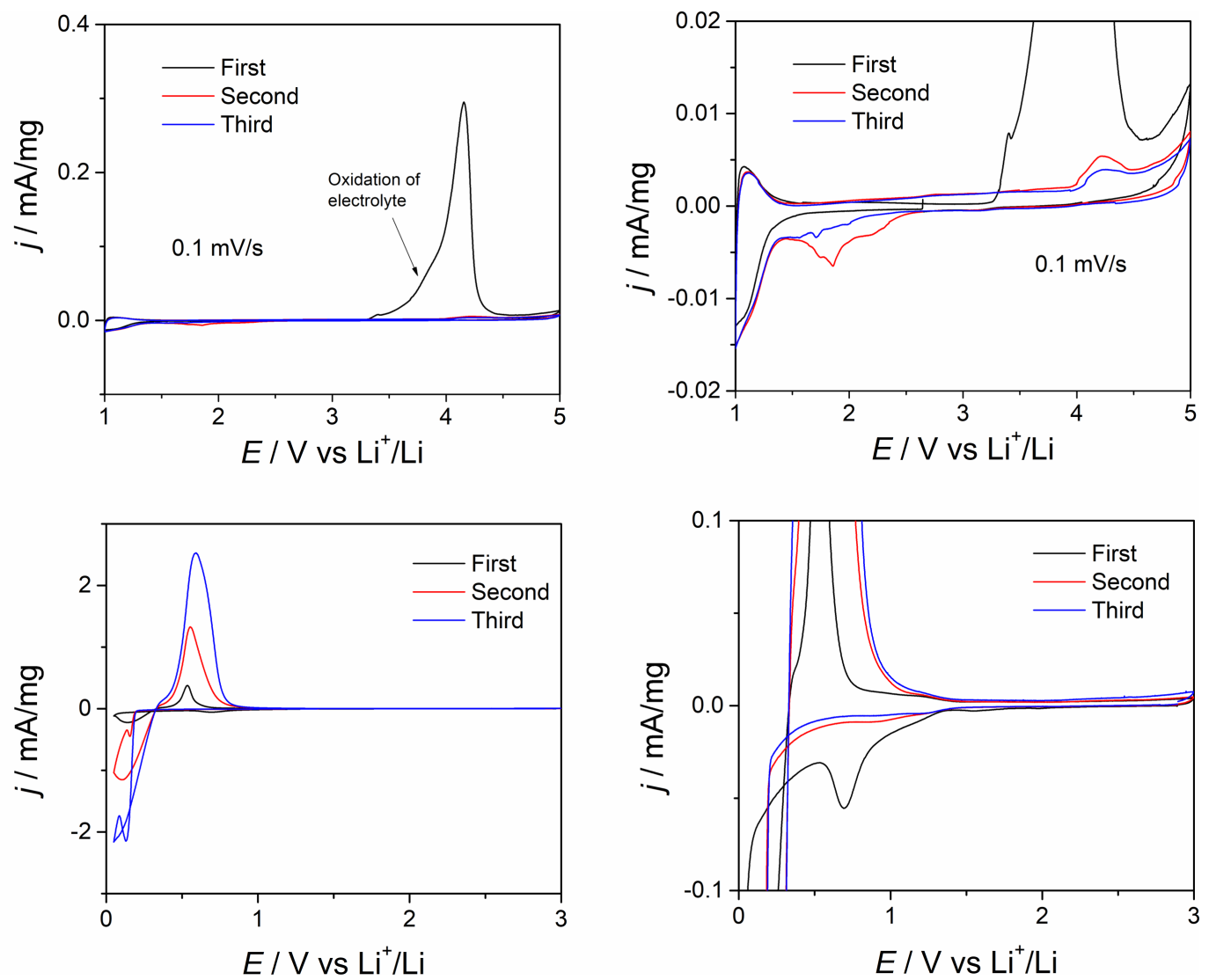

Figure 5: Cyclic voltammetry of a half-cell with $\mathrm{ErF}_{3}$ as working electrode and lithium foil as counter electrode at the different cut-off potentials. The figures at the right represent magnifications of the two left figures. 
Until now there has been no report on $\mathrm{ErF}_{3}$ applied as electrode material for $\mathrm{Li}^{+} / \mathrm{Li}$. Cyclic voltammetry was performed to address general aspects of the redox behaviour (Figure 5). In the range from 1.0 to $5.0 \mathrm{~V}$, during the reduction, a reduction process takes place starting at $1.5 \mathrm{~V}$, which may be attributed to the transformation of $\mathrm{Er}^{3+}$ to $\mathrm{Er}^{2+}$, which can be reversibly oxidized. During the oxidation process, oxidation of the electrolyte was observed, starting around $3.4 \mathrm{~V}$. Hence, such standard electrolytes cannot be applied to this redox couple. In the range from 1.0 to $0.05 \mathrm{~V}$, there is an overpotential electrodeposition process of $\mathrm{Al}^{3+}$, stemming from the $\mathrm{Al}$ collector, indicating that the used potential cannot be lower than $0.2 \mathrm{~V}$. The open-circuit potential (OCP) of the cell is around $2.7 \mathrm{~V}$ vs $\mathrm{Li}^{+} / \mathrm{Li}$.

The standard electrode potential values of the involved redox couples are: $\mathrm{Li}^{+}+\mathrm{e}^{-} \rightarrow \mathrm{Li}(-3.04 \mathrm{~V}$ vs SHE$), \mathrm{Er}^{3+}+3 \mathrm{e}^{-} \rightarrow \mathrm{Er}$ $\left(-2.33 \mathrm{~V}\right.$ vs SHE; $0.71 \mathrm{~V}$ vs $\left.\mathrm{Li}^{+} / \mathrm{Li}\right)$ and $\mathrm{Er}^{2+}+2 \mathrm{e} \rightarrow \mathrm{Er}$ $\left(-2.0 \mathrm{~V}\right.$ vs SHE; $\left.1.04 \mathrm{~V}_{\text {vs Li}}{ }^{+} / \mathrm{Li}\right)$. In conclusion, $\mathrm{ErF}_{3}$ does not exhibit reversible redox behaviour using common electrolytes, and thus more elaborate experimental effort is needed, including changing the potential range or electrolyte, or choosing $\mathrm{Cu}$ instead of $\mathrm{Al}$ for the current collector.

\section{RE-NPs from RE(amd) ${ }_{3}$ in [BMIm] $\left[\mathrm{NTf}_{2}\right]$}

Compared to the IL $[\mathrm{BMIm}]\left[\mathrm{BF}_{4}\right]$, which can act as a fluoride source, the hydrophobic IL $[\mathrm{BMIm}]\left[\mathrm{NTf}_{2}\right]$ with $\mathrm{C}-\mathrm{F}$ bound fluorine can be expected to be a more inert reaction medium. Further, this hydrophobic IL could be more readily dried to residual water levels (determined by Karl Fischer titration) of below $10 \mathrm{ppm}$ (cf. $30 \mathrm{ppm}$ for [BMIm] $\left[\mathrm{BF}_{4}\right]$ ). The rare-earth metal amidinates $\mathrm{RE}(\mathrm{amd})_{3}$ with $\mathrm{RE}=\operatorname{Pr}(\mathrm{III}), \mathrm{Gd}(\mathrm{III}), \mathrm{Er}(\mathrm{III})$ and $\mathrm{Eu}(\mathrm{dpm})_{3}$ were suspended in [BMIm] $\left[\mathrm{NTf}_{2}\right]$ and decomposed by microwave irradiation for $20 \mathrm{~min}$ at a temperature of $230{ }^{\circ} \mathrm{C}$ (Scheme 1 and Figure S3, Supporting Information File 1).
Rare-earth metal nanoparticles (RE-NPs) were obtained for $\mathrm{RE}=\mathrm{Gd}$ and Er. For $\operatorname{Pr}(\mathrm{amd})_{3}$ and $\mathrm{Eu}(\mathrm{dpm})_{3}$ no particles were seen in TEM investigations. The size and size distribution of the Gd-NPs and Er-NPs were determined by TEM (Figure 6 and Figure S7a, Supporting Information File 1) to values of $1.0-2.5 \mathrm{~nm}$ for Gd (average diameter of $1.5 \pm 0.5 \mathrm{~nm}$ ) and 2.0-3.5 nm for Er (average diameter $3.0 \pm 0.5 \mathrm{~nm}$ ) (Table 1). A close-up of the TEM images shows interference patterns, indicating crystallinity of the RE-NPs.

The crystallinity of the RE-NPs was confirmed by SAED and gave the expected reflections for elemental Gd and Er (Figure 7 and Figure S7b, Supporting Information File 1). Due to the very small size of the Gd and Er particles a meaningful PXRD pattern could not be obtained.

Characterization by EDX (Figure 7 and Figure S7b, Supporting Information File 1) gave the expected bands for $\mathrm{Gd}$ and Er. The small fluorine and sulfur peaks are due to residual IL around the nanoparticles (Figure S3, Supporting Information File 1). We suggest that the residual IL coverage of the RE-NPs also prevents their oxidation during the short air contact upon transfer from a Schlenk flask into the TEM and XPS.

The oxidation state zero of gadolinium and erbium, i.e., the formation of $\operatorname{Gd}(0)$ and $\operatorname{Er}(0)$ metal NPs were indirectly supported by the measured XPS binding energies of oxygen and fluorine (Figure 8, Table 3 and Figure S7c, Supporting Information File 1). An assignment of the measured RE (RE = Gd, Er) binding energies to metal(0) or metal(III) oxide was not possible because the binding energies are shifted strongly due to the very small size of the NPs. The measured XPS binding energies of oxygen and fluorine match very well with the literature values of organic oxygen and organic fluorine and thereby exclude the formation of RE(III) oxide or RE(III) fluoride for
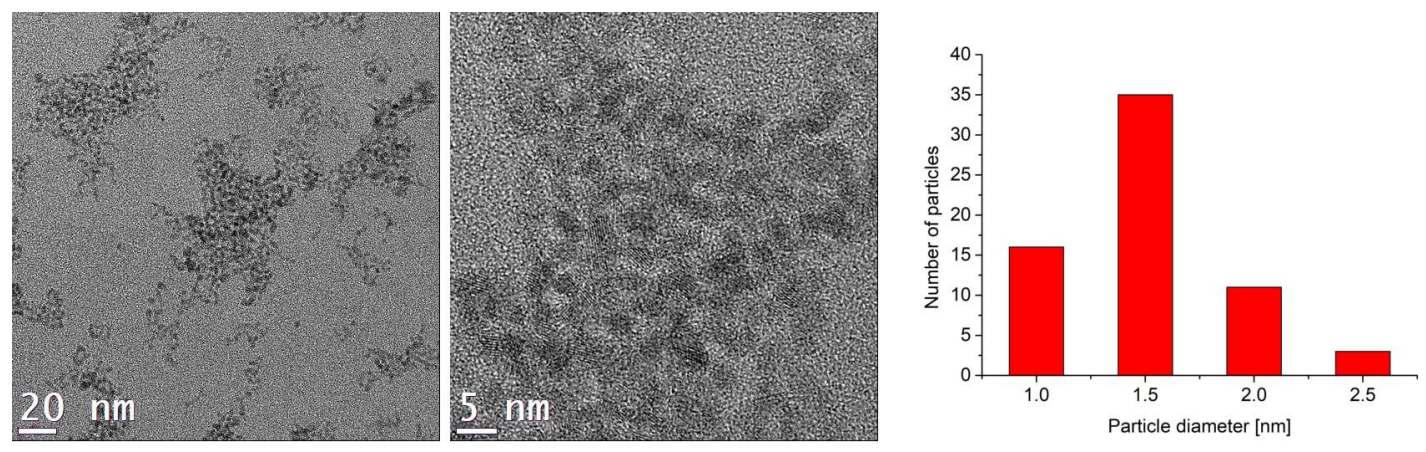

Figure 6: TEM images and particle size histogram of $1.0 \mathrm{wt} \% \mathrm{Gd}-\mathrm{NPs}$ in $[\mathrm{BMIm}]\left[\mathrm{NTf}_{2}\right]$ from Gd(amd) 3 . 

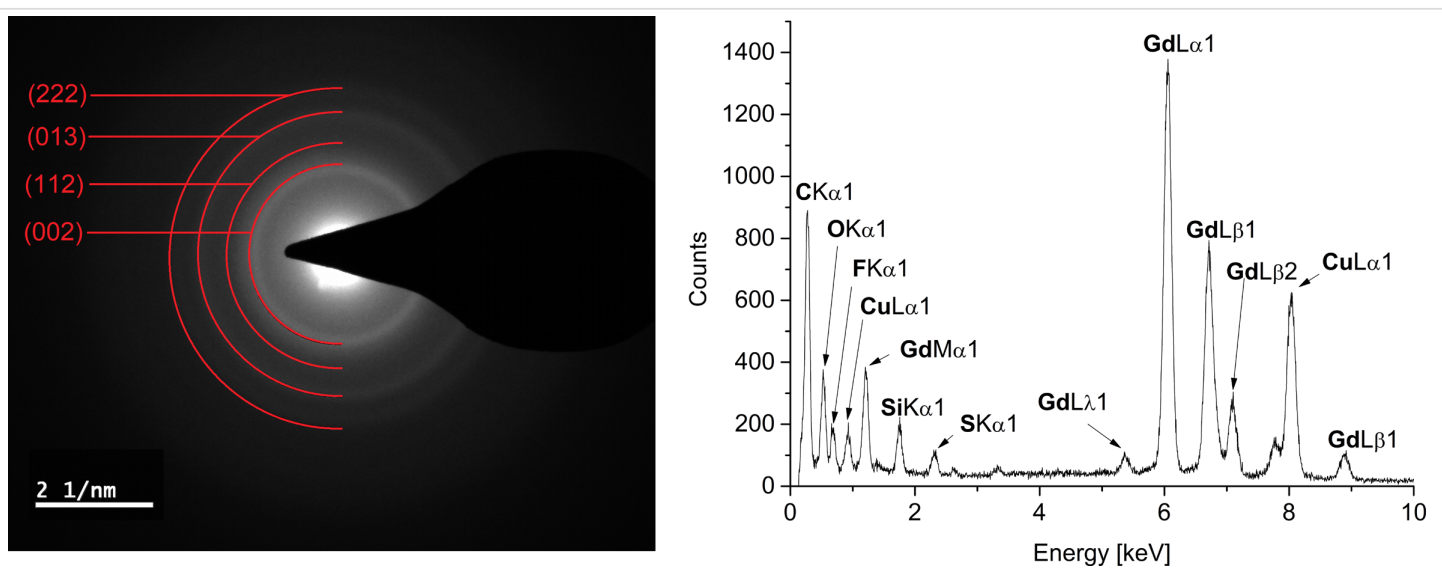

Figure 7: SAED (Gd reference peaks in red from COD 1522526, cubic crystal system with space group $/ m-3 m$ ) and EDX of 1.0 wt $\%$ Gd-NPs in $[\mathrm{BMIm}]\left[\mathrm{NTf}_{2}\right]$ from $\mathrm{Gd}(\mathrm{amd})_{3}$.
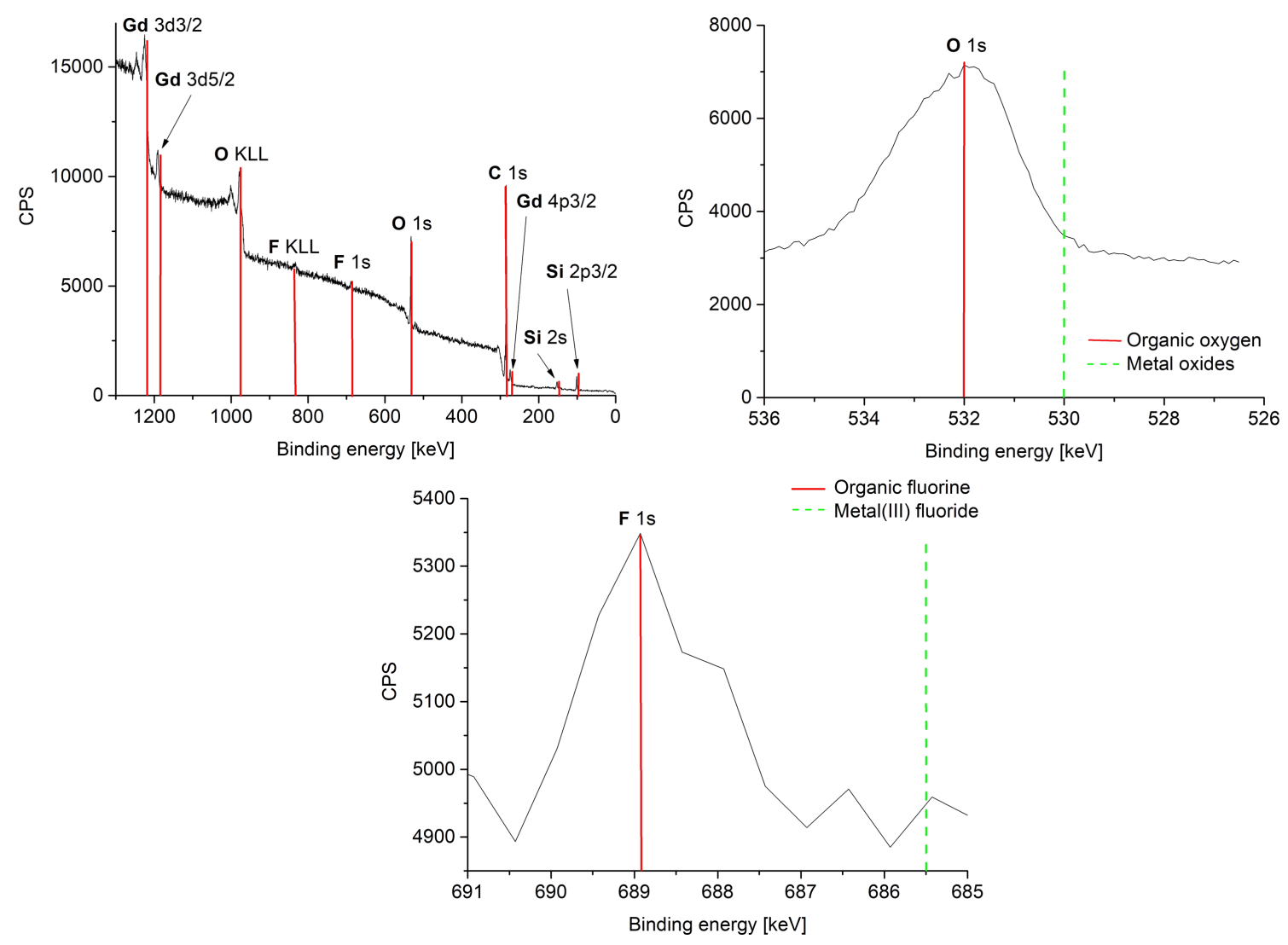

Figure 8: Overview and HR-XPS of $1.0 \mathrm{wt} \% \mathrm{Gd}-\mathrm{NPs}$ in $[\mathrm{BMIm}]\left[\mathrm{NTf}_{2}\right]$ from $\mathrm{Gd}(\mathrm{amd})_{3}$. The red and green bars are a guide to the eye on the bindingenergy axis.

$\mathrm{RE}=\mathrm{Gd}(0)$ and $\operatorname{Er}(0)[48,49]$. Thus, HR-XPS data in combination with SAED exclude any significant contamination of $\operatorname{Gd}(0)$-NPs and $\operatorname{Er}(0)$-NPs with oxides or fluorides. We note that the amount of metal oxides is below the detection limit and that small amounts of water in the ILs of up to $30 \pm 18 \mathrm{ppm}$ for $[\mathrm{BMIm}]\left[\mathrm{BF}_{4}\right]$ does not lead to a detectable formation of metal oxides. The water amount in the less hydrophilic IL [BMIm] $\left[\mathrm{NTf}_{2}\right]$ was even lower $(10 \mathrm{ppm})$.

\section{RE-NPs from RE(amd $)_{3}$ in PC}

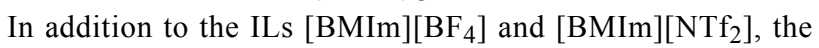
organic and dried solvent $\mathrm{PC}(<10 \mathrm{ppm}$ water content) 
Table 3: Comparison of XPS binding energies in RE-NP samples in [BMIm] $\left[\mathrm{NTf}_{2}\right]$.

\begin{tabular}{|c|c|c|c|}
\hline XPS signal & measured $[\mathrm{eV}]$ & $\begin{array}{l}\text { metal(III) oxides or metal(III) } \\
\text { fluorides }[\mathrm{eV}][48,49]\end{array}$ & $\begin{array}{l}\text { metal }(0) \text { and organic oxygen } \\
\text { or organic fluorine }[\mathrm{eV}][48,49]\end{array}$ \\
\hline \multicolumn{4}{|c|}{ Gd(0)-NPs [50] } \\
\hline $\mathrm{Gd} 3 \mathrm{~d}_{3 / 2}$ & 1225 & 1220 & 1218 \\
\hline $\mathrm{Gd} 3 \mathrm{~d}_{5 / 2}$ & 1191.5 & 1188 & 1186 \\
\hline $01 \mathrm{~s}$ & 532 & $529-530$ & $531.5-533^{a}$ \\
\hline $\mathrm{F} 1 \mathrm{~s}$ & 689 & $684-685.5$ & $688-689^{a}$ \\
\hline \multicolumn{4}{|c|}{$\operatorname{Er}(0)-N P s$} \\
\hline Er 4d & 174 & 170 & 167.5 \\
\hline $01 \mathrm{~s}$ & 534.5 & $529-530$ & $531.5-533^{a}$ \\
\hline F 1s & 690 & $684-685.5$ & $688-689^{a}$ \\
\hline
\end{tabular}

aEntry corresponds to the measured experimental value.

(Figure S3, Supporting Information File 1) was used for NP syntheses. The rare-earth metal amidinates $\mathrm{RE}(\mathrm{amd})_{3}$ with $\mathrm{RE}=\operatorname{Pr}(\mathrm{III}), \mathrm{Gd}(\mathrm{III}), \mathrm{Er}(\mathrm{III})$ and $\mathrm{Eu}(\mathrm{dpm})_{3}$ were suspended in $\mathrm{PC}$ and decomposed in the microwave reactor for up to $20 \mathrm{~min}$ at $230{ }^{\circ} \mathrm{C}$ (Scheme 1).

The microwave-assisted thermal decomposition gave rare-earth metal nanoparticles (RE-NPs). Again, for $\mathrm{Eu}(\mathrm{dpm})_{3}$ no parti- cles were seen in TEM investigations. The size and size distribution of the RE-NPs were determined by TEM (Figure 9 and Figures S8, S9a, Supporting Information File 1) to values of 1.5-3.5 nm for Pr, 1.0-2.5 nm for Gd and 4.0-7.0 nm for $\mathrm{Er}$ giving average diameters of $2 \pm 1 \mathrm{~nm}$ for $\operatorname{Pr}, 1.5 \pm 0.5 \mathrm{~nm}$ for $\mathrm{Gd}$ and $5 \pm 1 \mathrm{~nm}$ for Er (Table 1). Interference patterns for Pr-NPs and Gd-NPs in close-up TEM images (Figure 9 top and Figure S8, Supporting Information File 1) indicate crystallinity
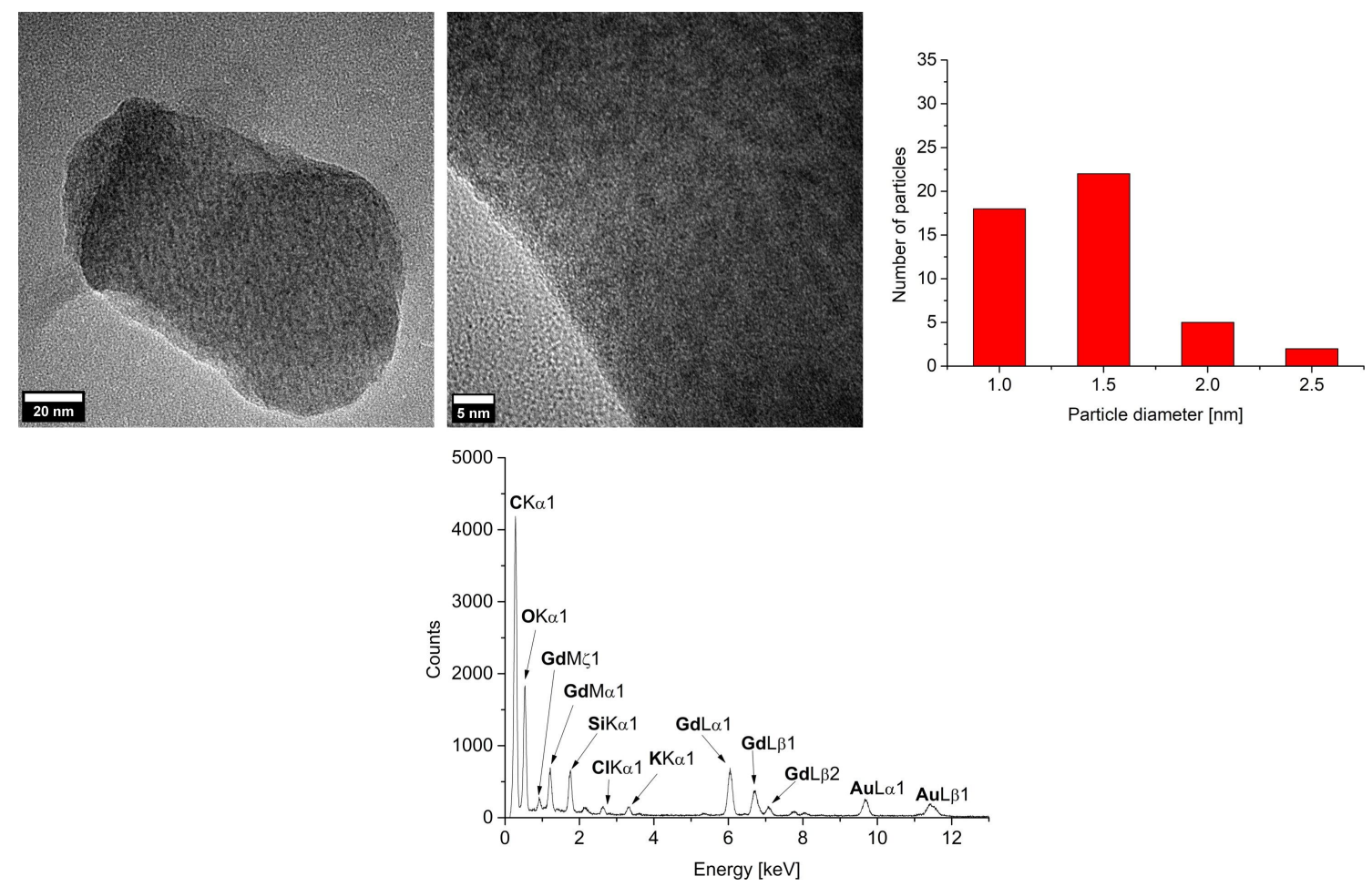

Figure 9: TEM images, particle-size histogram and EDX of $1.0 \mathrm{wt} \%$ Gd-NPs in PC from Gd(amd) 
of the RE-NPs. For the crystalline Er-NPs SAED gave the expected reflections of elemental erbium (Figure S9b, Supporting Information File 1). The very small size of the particles failed to yield meaningful PXRD patterns.

EDX (Figure 9 and Figure S9b, Supporting Information File 1) gave the expected bands for Gd and Er. No fluorine was detected by EDX analysis. The oxygen peak can be attributed mainly to air contamination when the sample was introduced into the TEM device.
Again, the formation of $\operatorname{Pr}(0), \operatorname{Gd}(0)$ and $\operatorname{Er}(0)$ metal NPs were indirectly supported by the measured XPS binding energies of oxygen (Figure 10, Table 4 and Figures S8b and S9c, Supporting Information File 1). The measured RE (RE $=\mathrm{Pr}$, Gd, Er) binding energies had again shifted due the small NP size so that no clear assignment to metal(0) or metal(III) could be made. The measured XPS binding energies of oxygen are in very good agreement with the binding energies of organic oxygen that are given in literature and thereby exclude the formation of $\mathrm{RE}(\mathrm{III})$ oxide for $\mathrm{RE}=\operatorname{Pr}(0), \operatorname{Gd}(0)$ and $\operatorname{Er}(0)$
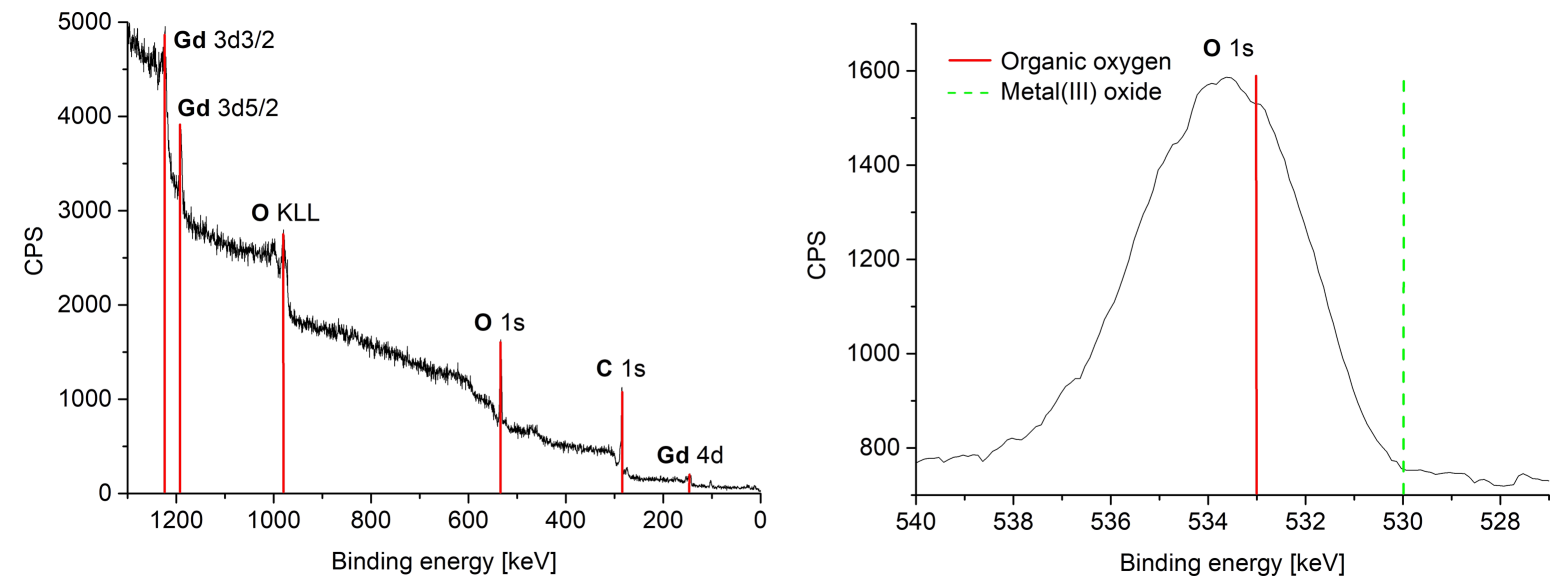

Figure 10: HR-XPS of $1.0 \mathrm{wt} \% \mathrm{Gd}-\mathrm{NPs}$ in PC from Gd(amd) 3 . The red and green bars are a guide to the eye on the binding-energy axis.

Table 4: Comparison of XPS binding energies in RE-NPs samples in PC.

\begin{tabular}{|c|c|c|c|}
\hline XPS signal & measured $[\mathrm{eV}]$ & $\begin{array}{l}\text { metal(III) oxides or metal(III) } \\
\quad \text { fluorides [eV] }[48,49]\end{array}$ & $\begin{array}{l}\text { metal }(0) \text { and organic oxygen } \\
\text { or organic fluorine }[\mathrm{eV}][48,49]\end{array}$ \\
\hline \multicolumn{4}{|c|}{$\operatorname{Pr}(0)-N P s$} \\
\hline $\operatorname{Pr} 3 d_{5 / 2}$ & 934 & 933-936 & 932 \\
\hline 0 1s & 532 & $529-530$ & $531.5-533^{a}$ \\
\hline F 1s & no signal & $684-685.5$ & $688-689^{a}$ \\
\hline \multicolumn{4}{|c|}{ Gd(0)-NPs [50] } \\
\hline $\mathrm{Gd} 3 \mathrm{~d}_{3 / 2}$ & 1223 & 1220 & 1218 \\
\hline $\mathrm{Gd} 3 \mathrm{~d}_{5 / 2}$ & 1191 & 1188 & 1186 \\
\hline Gd 4d & 146 & 144 & 140 \\
\hline $01 \mathrm{~s}$ & 533.5 & $529-530$ & $531.5-533^{a}$ \\
\hline F 1s & no signal & $684-685.5$ & $688-689^{a}$ \\
\hline \multicolumn{4}{|c|}{$\operatorname{Er}(0)-N P s$} \\
\hline Er 4d & 172 & 170 & 167.5 \\
\hline $01 \mathrm{~s}$ & 532.5 & $529-530$ & $531.5-533^{a}$ \\
\hline F 1s & no signal & $684-685.5$ & $688-689^{a}$ \\
\hline
\end{tabular}

aEntry corresponds to the measured experimental value. 
$[48,49]$. Understandably, the non-fluorous solvent PC (Figure S3, Supporting Information File 1) gave no signals for fluorine.

\section{Conclusion}

Microwave-assisted thermal decomposition [56-58] using the rare-earth metal(III) coordination compounds tris $\left(N, N^{\prime}\right.$-diisopropyl-2-methyl-amidinate) $\mathrm{RE}(\mathrm{amd})_{3}(\mathrm{RE}=\mathrm{Pr}(\mathrm{III}), \mathrm{Gd}(\mathrm{III})$, Er(III)) and tris(2,2,6,6-tetramethyl-3,5-heptanedionato)europium(III) $\left(\mathrm{Eu}(\mathrm{dpm})_{3}\right)$ as precursor compounds yield $\mathrm{REF}_{3}$ NPs in the IL $[\mathrm{BMIm}]\left[\mathrm{BF}_{4}\right]$ for $\mathrm{RE}=\mathrm{Pr}, \mathrm{Eu}, \mathrm{Gd}$ and $\mathrm{Er}$ and very small RE-NPs in the IL $[\mathrm{BMIm}]\left[\mathrm{NTf}_{2}\right]$ and in propylene carbonate $(\mathrm{PC})$ for $\mathrm{RE}=\mathrm{Pr}, \mathrm{Gd}$ and Er. The phase purity and the absence of oxide impurities was proven by powder X-ray diffraction (PXRD), selected area electron diffraction (SAED) and high-resolution X-ray photoelectron spectroscopy (HRXPS). To the best of our knowledge, there have been so far no reports on the synthesis of non-oxidized nanoparticles of any rare-earth element by soft-wet chemical routes from metalorganic precursors. However, access to a simple, reproducible and scalable method to obtain RE-NPs in solution will be the key for developing the nano-chemistry of non-oxide (and nonfluoride) RE materials. Our results on praseodymium, gadolinium and erbium nanoparticles derived from microwaveassisted thermolysis of the respective metal amidinates $\mathrm{RE}(\mathrm{amd})_{3}$ as precursors may open up new avenues for applications of pure rare-earth metal nanoparticles and nanomaterials derived from these. In particular we are aiming to study the nano-alloying of RE-NPs with late transition metals M and study the catalytic properties of the obtained intermetallic $\mathrm{M} / \mathrm{RE}-\mathrm{NPs}$ in extension of our previous work on $\mathrm{Ni} / \mathrm{Ga}$ nanophases derived from organometallic precursors by co-thermolysis in ILs and PC [59].

\section{Experimental}

All synthesis experiments were carried out with Schlenk techniques under nitrogen or argon since the amidinates are hygroscopic and air sensitive. Propylene carbonate (PC) was obtained from Sigma Aldrich (99.7\%) and was dried under high vacuum $(1.0 \mathrm{~Pa})$ for a few days. The water content of PC measured by using coulometric Karl Fischer titration (ECH/ Analytik Jena AQUA 40.00) was less than 10 ppm. Methyllithium, 1,3-diisopropylcarbodiimide ( $>99 \%)$ and praseodymium(III) chloride ( $>99 \%$ ) were purchased from SigmaAldrich and used without further purification. Tris(2,2,6,6-tetramethyl-3,5-heptanedionato)europium(III) (>99\%) was purchased from Alfa Aesar and was dried under high vacuum $\left(10^{-3}\right.$ mbar). 1-chlorobutane (>99\%) and 1-methylimidazole (>99\%) were obtained from Sigma-Aldrich and purified by fractional distillation, then dried over $4 \AA$ molecular sieves for several days.
The syntheses of the rare-earth metal amidinates $\left(\operatorname{RE}(\mathrm{amd})_{3}\right.$, $\mathrm{RE}=\mathrm{Gd}, \mathrm{Er}, \mathrm{Pr}$ ) were performed according to literature procedures [60-63]. The rare-earth metal amidinates $\mathrm{RE}(\mathrm{amd})_{3}$ were synthesized by an insertion reaction of methyl lithium into 1,3diisopropylcarbodiimide in THF. The resulting lithium amidinate solution was reacted with the RE halides in a salt metathesis reaction.

The ionic liquids (ILs) [BMIm] $\left[\mathrm{BF}_{4}\right]$ and $[\mathrm{BMIm}]\left[\mathrm{NTf}_{2}\right]$ were synthesized by reacting 1-methylimidazole with 1-chlorobutane to yield $[\mathrm{BMIm}][\mathrm{Cl}]$. The $[\mathrm{BMIm}][\mathrm{Cl}]$ reacted with $\mathrm{HBF}_{4}$ or $\mathrm{LiNTf}_{2}$ to give $[\mathrm{BMIm}]\left[\mathrm{BF}_{4}\right]$ or $[\mathrm{BMIm}]\left[\mathrm{NTf}_{2}\right][64]$. The IL was dried under ultra-high vacuum $\left(10^{-7} \mathrm{mbar}\right)$ at $70{ }^{\circ} \mathrm{C}$ for several days. The characterization was carried out by ${ }^{1} \mathrm{H}$ and ${ }^{13} \mathrm{C}$ NMR. Quantitative anion exchange and, thus, IL purity was assessed by ion chromatography (Dionex ICS-1100, with IonPac ${ }^{\circledR} \mathrm{AS} 22,4 \times 250 \mathrm{~mm}$ column) to be $>99 \%$ for both ILs. The water content by coulometric Karl Fischer titration was less than $10 \mathrm{ppm}$ for $[\mathrm{BMIm}]\left[\mathrm{NTf}_{2}\right]$ and $30 \pm 18 \mathrm{ppm}$ for $[\mathrm{BMIm}]\left[\mathrm{BF}_{4}\right]$.

Synthesis procedures of rare-earth metal nanoparticles (RENPs) and rare-earth fluoride nanoparticles ( $\left.\mathrm{REF}_{3}-\mathrm{NPs}\right)$ were based on previous literature [12]. All syntheses were carried out under inert conditions. The rare-earth metal amidinate precursors/[Eu(dpm $\left.)_{3}\right]$ were suspended at room temperature in the dried ILs $[\mathrm{BMIm}]\left[\mathrm{BF}_{4}\right],[\mathrm{BMIm}]\left[\mathrm{NTf}_{2}\right]$ or in PC. In contrast to the $\mathrm{PrF}_{3}$ - and $\mathrm{EuF}_{3}-\mathrm{NPs}$ syntheses of Schmitz et al. [12], the rare-earth metal amidinate precursors and $\left[\mathrm{Eu}(\mathrm{dpm})_{3}\right]$ were decomposed by microwave irradiation (CEM, Discover) for $20 \mathrm{~min}$ at a power of $50 \mathrm{~W}$ to a temperature of $230{ }^{\circ} \mathrm{C}$ (cf. $15 \mathrm{~min}, 50 \mathrm{~W}, 220^{\circ} \mathrm{C}$ ). The mass of the metal was adjusted to obtain $1.0 \mathrm{wt} \%$ NPs in IL or PC dispersion.

HR-X-ray photoelectron spectroscopy: HR-XPS (ESCA) measurements were performed with a Fisons/VG Scientific ESCALAB $200 \mathrm{X}$ xp-spectrometer, operating at $70-80{ }^{\circ} \mathrm{C}$, a pressure of $7.0 \times 10^{-9}$ mbar and a sample angle of $33^{\circ}$. Spectra were recorded using polychromatic $\mathrm{Al} \mathrm{K} \alpha$ excitation $(11 \mathrm{kV}, 20 \mathrm{~mA})$ and an emission angle of $0^{\circ}$. Calibration of the XPS was carried out by recording spectra with Al K $\alpha$ $\mathrm{X}$-rays from clean samples of copper, silver and gold at $50 \mathrm{eV}$ and $10 \mathrm{eV}$ pass energy and comparison with reference values.

Powder X-ray diffraction: PXRD data were measured at ambient temperature on a Bruker D2-Phaser using a flat sample holder and $\mathrm{Cu} \mathrm{K} \alpha$ radiation $(\lambda=1.54182 \AA, 35 \mathrm{kV})$. Samples had been precipitated with ethanenitrile from the NP/IL dispersion and washed several times with ethanenitrile. PXRDs were measured for $1 \mathrm{~h}$. Small shifts in PXRD patterns are not 
uncommon for nanoparticles. A number of effects can be considered for such shifts including the range of stoichiometric composition, partly inhomogeneous element distribution, defects such as stacking and twin faults and nanosized crystalline domains being much smaller than the bulk reference material causing lattice contraction or expansion and strain [6569].

Transmission electron microscopy: TEM was performed with a FEI Tecnai G2 F20 electron microscope operated at $200 \mathrm{kV}$ accelerating voltage [70]. Conventional TEM images were recorded with a Gatan UltraScan 1000P detector. High-angle annular dark-field scanning transmission electron microscopy (HAADF-STEM) as shown in Figure S4a (Supporting Information File 1) was also performed with this microscope. TEM samples were prepared by drop-casting the diluted material on $200 \mu \mathrm{m}$ carbon-coated copper grids or gold grids. The size distribution was determined manually or with the aid of the Gatan Digital Micrograph software from at least 50 (if not stated otherwise) individual particles. EDX spectra for composition analysis were recorded with the same instrument using an exposure time of $3 \mathrm{~min}$.

Selected area electron diffraction: SAED patterns (Figures S4 and S6, Supporting Information File 1) have been recorded with an FEI Titan 80-300 TEM [71], operated at $300 \mathrm{kV}$ accelerating voltage. The area selection was achieved with a round aperture placed in the first intermediate image plane with a corresponding diameter of $0.64 \mu \mathrm{m}$ in the object plane. For each acquisition a sample region with a significant amount of material was placed inside the aperture. The objected was illuminated with wide-spread parallel beam obtaining focused diffraction patterns. The diffraction images were calibrated with Debye-Scherrer patterns recorded from a gold reference sample (S106, Plano GmbH, Wetzlar, Germany).

Thermogravimetric analysis: TGA was performed with Netzsch TG 209 F3 Tarsus equipped with an Al crucible by using a heating rate of $10 \mathrm{~K} \cdot \mathrm{min}^{-1}$.

Electrochemical measurements: The $\mathrm{ErF}_{3}$ working electrodes were prepared by coating an ( $N$-methyl pyrrolidone)-based slurry composed of $75 \mathrm{wt} \% \mathrm{ErF}_{3}, 15 \mathrm{wt} \%$ conductive agents (Super P active carbon from Temical) and $10 \mathrm{wt} \%$ binder (PVDF) on a current collector (aluminium foil). A half-cell was assembled in an Ar-filled glovebox, with lithium foil as a counter electrode and $1 \mathrm{M} \mathrm{LiPF}_{6}$ in ethylene carbonate-ethyl methyl carbonate (50:50) as the electrolyte. The cyclic voltammetry $(\mathrm{CV})$ data of these half-cells were collected utilizing an electrochemical workstation (Autolab 302) with different cutoff potentials.

\section{Supporting Information}

Supporting Information contains: thermogravimetric analysis, TGA of rare-earth metal amidinates and $\mathrm{Eu}(\mathrm{dpm})_{3}$, structural formulas of the ionic liquids (ILs) and propylene carbonate (PC), TEM images, particle size histogram, PXRD, SAED, EDX and XPS of $\mathrm{REF}_{3}-\mathrm{NPs}$, TEM images, particle size histogram, SAED, EDX and XPS of Er-NPs in [BMIm] $\left[\mathrm{NTf}_{2}\right.$ ], TEM images, particle size histogram, SAED, EDX and XPS of RE-NPs in PC.

\section{Supporting Information File 1}

Additional experimental data.

[https://www.beilstein-journals.org/bjnano/content/ supplementary/2190-4286-9-180-S1.pdf]

\section{Acknowledgements}

Authors are thankful to the Deutsche Forschungsgemeinschaft (DFG) for financial support in the priority project SPP 1708 through grant Ja466/31-1, Ja466/31-2, Fi502/32-1, PO780/14-1 and the Ernst Ruska-Centre core facilities program through grant MA 1280/40-1. The authors from RUB acknowledge the DFG (project DE-790-11-1) for supporting this work. The authors also gratefully acknowledge technical assistance by Max-Planck-Institut für Eisenforschung $\mathrm{GmbH}$, Düsseldorf for TEM measurements.

\section{ORCID ${ }^{\circledR}$ iDs}

Marvin Siebels - https://orcid.org/0000-0002-3288-2795 Lukas Mai - https://orcid.org/0000-0001-8949-0736 Laura Schmolke - https://orcid.org/0000-0002-2369-9331 Juri Barthel - https://orcid.org/0000-0003-3914-4346 Anjana Devi - https://orcid.org/0000-0003-2142-8105 Roland A. Fischer - https://orcid.org/0000-0002-7532-5286 Christoph Janiak - https://orcid.org/0000-0002-6288-9605

\section{References}

1. Ghobadi, M.; Gharabaghi, M.; Abdollahi, H.; Kisomi, A. S. New J. Chem. 2017, 41, 11906-11914. doi:10.1039/C7NJ02125A

2. Das, N.; Das, D. J. Rare Earths 2013, 31, 933-943. doi:10.1016/S1002-0721(13)60009-5

3. Eliseeva, S. V.; Bünzli, J.-C. G. New J. Chem. 2011, 35, 1165-1176. doi:10.1039/c0nj00969e

4. Escudero, A.; Carrillo-Carrion, C.; Zyuzin, M. V.; Parak, W. J. Top. Curr. Chem. 2016, 374, 48. doi:10.1007/s41061-016-0049-8

5. Bouzigues, C.; Gacoin, T.; Alexandrou, A. ACS Nano 2011, 5 , 8488-8505. doi:10.1021/nn202378b

6. Nelson, J. A.; Bennett, L. H.; Wagner, M. J. J. Am. Chem. Soc. 2002, 124, 2979-2983. doi:10.1021/ja0122703

7. Hansen, P.; Clausen, C.; Much, G.; Rosenkranz, M.; Witter, K. J. Appl. Phys. 1989, 66, 756-767. doi:10.1063/1.343551 
8. Mai, H.-X.; Zhang, Y.-W.; Si, R.; Yan, Z.-G.; Sun, L.-d.; You, L.-P.; Yan, C.-H. J. Am. Chem. Soc. 2006, 128, 6426-6436. doi:10.1021/ja060212h

9. Schütte, K.; Meyer, H.; Gemel, C.; Barthel, J.; Fischer, R. A.; Janiak, C. Nanoscale 2014, 6, 3116-3126. doi:10.1039/c3nr05780a

10. Bahlawane, N.; Kohse-Höinghaus, K.; Premkumar, P. A.; Lenoble, D. Chem. Sci. 2012, 3, 929-941. doi:10.1039/C1SC00522G

11. Kim, M. R.; Xu, Z.; Chen, G.; Ma, D. Chem. - Eur. J. 2014, 20 , 11256-11275. doi:10.1002/chem.201402277

12. Schmitz, A.; Schütte, K.; llievski, V.; Barthel, J.; Burk, L.; Mülhaupt, R.; Yue, J.; Smarsly, B.; Janiak, C. Beilstein J. Nanotechnol. 2017, 8, 2474-2483. doi:10.3762/bjnano.8.247

13. Barker, J.; Kilner, M. Coord. Chem. Rev. 1994, 133, 219-300. doi:10.1016/0010-8545(94)80059-6

14. Schuchmann, D.; Westphal, U.; Schulz, S.; Flörke, U.; Bläser, D.; Boese, R. Angew. Chem. 2009, 121, 821-824. doi:10.1002/ange.200803736

15. Dagorne, S.; Guzei, I. A.; Coles, M. P.; Jordan, R. F. J. Am. Chem. Soc. 2000, 122, 274-289. doi:10.1021/ja992104j

16. Sita, L. R.; Babcock, J. R. Organometallics 1998, 17, 5228-5230. doi:10.1021/om980706q

17. Krisyuk, V.; Aloui, L.; Prud'homme, N.; Sysoev, S.; Senocq, F.; Samélor, D.; Vahlas, C. Electrochem. Solid-State Lett. 2011, 14, D26-D29. doi:10.1149/1.3526142

18. Moni, P.; Al-Obeidi, A.; Gleason, K. K. Beilstein J. Nanotechnol. 2017, 8, 723-735. doi:10.3762/bjnano.8.76

19. Komissarov, I. V.; Kovalchuk, N. G.; Labunov, V. A.; Girel, K. V.; Korolik, O. V.; Tivanov, M. S.; Lazauskas, A.; Andrulevicius, M.; Tamulevicius, T.; Grigaliunas, V.; Meskinis, S.; Tamulevicius, S.; Prischepa, S. L. Beilstein J. Nanotechnol. 2017, 8, 145-158. doi:10.3762/bjnano.8.15

20. Coyle, J. P.; Monillas, W. H.; Yap, G. P. A.; Barry, S. T. Inorg. Chem. 2008, 47, 683-689. doi:10.1021/ic701317y

21. Taubert, A. Acta Chim. Slov. 2005, 52, 168-170.

22. Waltz, F.; Swider, A. M.; Hoyer, P.; Hassel, T.; Erne, M.; Möhwald, K.; Adlung, M.; Feldhoff, A.; Wickleder, C.; Bach, F.-W.; Behrens, P. J. Mater. Sci. 2012, 47, 176-183. doi:10.1007/s10853-011-5785-0

23. Yan, C.; Wagner, M. J. Nano Lett. 2013, 13, 2611-2614. doi:10.1021/nl400720n

24. Furukawa, S.; Komatsu, T. ACS Catal. 2017, 7, 735-765. doi:10.1021/acscatal.6b02603

25. Greeley, J.; Stephens, I. E. L.; Bondarenko, A. S.; Johansson, T. P.; Hansen, H. A.; Jaramillo, T. F.; Rossmeisl, J.; Chorkendorff, I.; Nørskov, J. K. Nat. Chem. 2009, 1, 552-556. doi:10.1038/nchem.367

26. Kanady, J. S.; Leidinger, P.; Haas, A.; Titlbach, S.; Schunk, S.; Schierle-Arndt, K.; Crumlin, E. J.; Wu, C. H.; Alivisatos, A. P. J. Am. Chem. Soc. 2017, 139, 5672-5675. doi:10.1021/jacs.7b01366

27. Campbell, P. S.; Prechtl, M. H. G.; Santini, C. C.; Haumesser, P.-H. Curr. Org. Chem. 2013, 17, 414-429. doi:10.2174/1385272811317040008

28. Freudenmann, D.; Wolf, S.; Wolff, M.; Feldmann, C. Angew. Chem., Int. Ed. 2011, 50, 11050-11060. doi:10.1002/anie.201100904

29. Ahmed, E.; Breternitz, J.; Groh, M. F.; Ruck, M. CrystEngComm 2012, 14, 4874-4885. doi:10.1039/c2ce25166c

30. Ahmed, E.; Ruck, M. Dalton Trans. 2011, 40, 9347-9357. doi:10.1039/c1dt10829h

31. Groh, M. F.; Müller, U.; Ahmed, E.; Rothenberger, A.; Ruck, M. Z. Naturforsch., B 2013, 68, 1108-1122. doi:10.5560/ZNB.2013-3141
32. Janiak, C. Z. Naturforsch., B 2013, 68, 1059-1089. doi:10.5560/znb.2013-3140

33. Marquardt, D.; Janiak, C. Nachr. Chem. 2013, 61, 754-757. doi:10.1002/nadc.201390235

34. Schmid, G. Nanoparticles; Wiley-VCH: Weinheim, Germany, 2004.

35. Antonietti, M.; Kuang, D.; Smarsly, B.; Zhou, Y. Angew. Chem., Int. Ed. 2004, 43, 4988-4992. doi:10.1002/anie.200460091

36. Astruc, D.; Lu, F.; Aranzaes, J. R. Angew. Chem., Int. Ed. 2005, 44, 7852-7872. doi:10.1002/anie.200500766

37. Kaper, H.; Endres, F.; Djerdj, I.; Antonietti, M.; Smarsly, B. M.; Maier, J.; Hu, Y.-S. Small 2007, 3, 1753-1763. doi:10.1002/smll.200700138

38. Wasserscheid, P.; Keim, W. Angew. Chem., Int. Ed. 2000, 39, 3772-3789. doi:10.1002/1521-3773(20001103)39:21<3772::AID-ANIE3772>3.0.CO ;2-5

39. Bayardon, J.; Holz, J.; Schäffner, B.; Andrushko, V.; Verevkin, S.; Preetz, A.; Börner, A. Angew. Chem. 2007, 46, 5971-5974. doi:10.1002/ange.200700990

40. Verevkin, S. P.; Emel'yanenko, V. N.; Toktonov, A. V.; Chernyak, Y.; Schäffner, B.; Börner, A. J. Chem. Thermodyn. 2008, 40, 1428-1432. doi:10.1016/j.jct.2008.05.001

41. Schäffner, B.; Verevkin, S. P.; Börner, A. Chem. Unserer Zeit 2009, 43, 12-21. doi:10.1002/ciuz.200900468

42. Schütte, K.; Barthel, J.; Endres, M.; Siebels, M.; Smarsly, B. M.; Yue, J.; Janiak, C. ChemistryOpen 2017, 6, 137-148. doi:10.1002/open.201600105

43. Archer, D. G.; Widegren, J. A.; Kirklin, D. R.; Magee, J. W. J. Chem. Eng. Data 2005, 50, 1484. doi:10.1021/je050136i

44. Freire, M. G.; Neves, C. M. S. S.; Marrucho, I. M.; Coutinho, J. A. P.; Fernandes, A. M. J. Phys. Chem. A 2010, 114, 3744-3749. doi:10.1021/jp903292n

45. Rutz, C.; Schmolke, L.; Gvilava, V.; Janiak, C. Z. Anorg. Allg. Chem. 2017, 643, 130-135. doi:10.1002/zaac.201600437

46. Olchowka, J.; Suta, M.; Wickleder, C. Chem. - Eur. J. 2017, 23 , 12092-12095. doi:10.1002/chem.201702375

47. Lorbeer, C.; Behrends, F.; Cybinska, J.; Eckert, H.; Mudring, A.-V. J. Mater. Chem. C 2014, 2, 9439-9450. doi:10.1039/C4TC01214C

48. Thermo Scientific XPS: Knowledge Base. http://xpssimplified.com/periodictable.php (accessed March 1, 2018).

49. Moulder, J. F.; Stickle, W. F.; Sobol, P. E.; Bomben, K. D. In Handbook of X-ray Photoelectron Spectroscopy; Chastain, J., Ed.; Perkin-Elmer Corporation: New York, NY, U.S.A., 1992.

50. Raiser, D.; Deville, J. P. J. Electron Spectrosc. Relat. Phenom. 1991, 57, 91-97. doi:10.1016/0368-2048(91)85016-M

51. Antipov, E. V.; Khasanova, N. R.; Fedotov, S. S. IUCrJ 2015, 2, 85-94. doi:10.1107/S205225251402329X

52. Poizot, P.; Laruelle, S.; Grugeon, S.; Dupont, L.; Tarascon, J.-M. Nature 2000, 407, 496-499. doi:10.1038/35035045

53. Tarascon, J.-M.; Armand, M. Nature 2001, 414, 359-367. doi: $10.1038 / 35104644$

54. Breitung, B.; Reddy, M. A.; Chakravadhanula, V. S. K.; Engel, M.; Kübel, C.; Powell, A. K.; Hahn, H.; Fichtner, M. Beilstein J. Nanotechnol. 2013, 4, 705-713. doi:10.3762/bjnano.4.80

55. Yamakawa, N.; Jiang, M.; Key, B.; Grey, C. P. J. Am. Chem. Soc. 2009, 131, 10525-10536. doi:10.1021/ja902639w

56. Bilecka, I.; Niederberger, M. Nanoscale 2010, 2, 1358-1374. doi:10.1039/b9nr00377k

57. Chen, W.; Gutmann, B.; Kappe, C. O. ChemistryOpen 2012, 1, 39-48. doi:10.1002/open.201100013 
58. Rodríguez, A. M.; Prieto, P.; de la Hoz, A.; Díaz-Ortíz, A.; Martín, R.; García, J. I. ChemistryOpen 2015, 4, 308-317.

doi:10.1002/open.201402123

59. Schütte, K.; Doddi, A.; Kroll, C.; Meyer, H.; Wiktor, C.; Gemel, C.; van Tendeloo, G.; Fischer, R. A.; Janiak, C. Nanoscale 2014, 6, 5532-5544. doi:10.1039/C4NR00111G

60. Krasnopolski, M.; Hrib, C. G.; Seidel, R. W.; Winter, M.; Becker, H.-W.; Rogalla, D.; Fischer, R. A.; Edelmann, F. T.; Devi, A. Inorg. Chem. 2013, 52, 286-296. doi:10.1021/ic301826s

61. Krasnopolski, M. Metalorganic chemical vapor deposition (MOCVD) routes for fabrication of rare earth nitride thin films : precursor evaluation, thin film deposition and characterization. Ph.D. Thesis, Ruhr-Universität Bochum, Bochum, Germany, 2014.

62. Lim, B. S.; Rahtu, A.; Park, J.-S.; Gordon, R. G. Inorg. Chem. 2003, 42, 7951-7958. doi:10.1021/ic0345424

63. Schmidt, S.; Schulz, S.; Bläser, D.; Boese, R.; Bolte, M. Organometallics 2010, 29, 6097-6103. doi:10.1021/om1008549

64. Zhou, J.; Zhang, D.; Zhang, X.; Song, H.; Chen, X. ACS Appl. Mater. Interfaces 2014, 6, 21223-21229. doi:10.1021/am506236n

65. Makinson, J. D.; Lee, J. S.; Magner, S. H.; De Angelis, R. J.; Weins, W. N.; Hieronymus, A. S. Adv. X-Ray Anal. 2000, 42, 407.

66. Kurian, M.; Kunjachan, C. Nano-Struct. Nano-Objects 2015, 1, 15. doi:10.1016/j.nanoso.2015.06.002

67. Zhang, F.; Chan, S.-W.; Spanier, J. E.; Apak, E.; Jin, Q.; Robinson, R. D.; Herman, I. P. Appl. Phys. Lett. 2002, 80, 127-129. doi:10.1063/1.1430502

68. Reddy, K. M.; Manorama, S. V.; Reddy, A. R. Mater. Chem. Phys. 2003, 78, 239. doi:10.1016/S0254-0584(02)00343-7

69. Manhas, M.; Kumar, V.; Sharma, V.; Ntwaeaborwa, O. M.; Swart, H. C. Nano-Struct. Nano-Objects 2015, 3, 9. doi:10.1016/j.nanoso.2015.06.003

70. Ernst Ruska-Centre for Microscopy and Spectroscopy with Electrons (ER-C). J. Large-Scale Res. Facil. 2016, 2, A77. doi:10.17815/jlsrf-2-138

71. Ernst Ruska-Centre for Microscopy and Spectroscopy with Electrons (ER-C). J. Large-Scale Res. Facil. 2016, 2, A41. doi:10.17815/jlsrf-2-66

\section{License and Terms}

This is an Open Access article under the terms of the Creative Commons Attribution License (http://creativecommons.org/licenses/by/4.0), which permits unrestricted use, distribution, and reproduction in any medium, provided the original work is properly cited.

The license is subject to the Beilstein Journal of Nanotechnology terms and conditions: (https://www.beilstein-journals.org/bjnano)

The definitive version of this article is the electronic one which can be found at: doi:10.3762/bjnano.9.180 